\title{
Food habits of the Cougar Puma concolor (Carnivora: Felidae) in the Central Andes of the Colombian Coffee Region
}

\author{
Diana Camila Muñoz Castillo ${ }^{1,4}$; Pauline Perry Arbeláez ${ }^{1,5}$; Héctor Fabio Arias-Monsalve ${ }^{1,3,6}$ \& Héctor E. Ramírez-Chaves ${ }^{1,2,7}$ \\ ${ }^{1}$ Universidad de Caldas (UCALDAS), Facultad de Ciencias Exactas y Naturales, Departamento de Ciencias Biológicas. Manizales, Caldas, Colombia. \\ 2 Universidad de Caldas (UCALDAS), Museo de Historia Natural, Centro de Museos. Manizales, Caldas, Colombia. \\ 3 Fundación Ecológica Cafetera (FEC). Manizales, Caldas, Colombia. \\ ${ }^{4}$ ORCID: http://orcid.org/0000-0002-3205-5001.E-mail: dianacami7@gmail.com \\ ${ }^{5}$ ORCID: http://orcid.org/0000-0002-4013-3524.E-mail: p.perry9250@gmail.com \\ ${ }^{6}$ ORCID: http://orcid.org/0000-0003-0783-2611. E-mail: hectorfabioariasmonsalve@gmail.com (Programa Maestría en Ciencias) \\ 7 ORCID: http://orcid.org/0000-0002-2454-9482. E-mail: hector.ramirez@ucaldas.edu.co
}

\begin{abstract}
The feeding habits of the cougar have been scarcely studied in Colombia, despite its importance in the ecosystems it inhabits. In this study, we analysed the diet of the cougar using 53 feces samples collected from several sites in the Central Andes of Colombia's Coffee Growing Region. To identify prey species, we examined and compared bone fragments and hairs found in each sample with descriptions published in relevant literature and with specimens from the Natural History Museum of the Universidad de Caldas, Colombia. We found that rabbits (Sylvilagus sp.) provided half of the relative biomass consumed by the cougar (50\%). Other preys identified belong to representatives of medium and large mammals such as marsupials (Didelphis: 10\%), sloths (Choloepus: 9\%), rodents (Coendou: 10\%, Cuniculus: 9\%), and deer (Mazama: 9\%). Of the preys, Coendou rufescens has not, to our knowledge, been previously included in cougar diet literature. The curve of accumulation of species indicated that the number of samples obtained in this work fully describe the diet of this feline. Neither domestic species were recorded in this work, nor were there any relationships between the dry or rainy seasons and the consumption of prey species. The comparison of the information reported in this study and others carried out in the Andes may indicate the general nature of this feline's diet and its adaptability to the prey species found in each area, since these vary in each one of them. It is probable that the obtained trophic niche value $(0.33)$ is due to the abundance of rabbits present in the study area. It is also probable that the cougar has not consumed domestic species since, although it is close to cattle ranches, it has enough of wild prey in the area to supply its needs. The results of this study may help to improve our understanding of the feeding habits of this predator and its interaction with other species in this important region of Colombia. This will, in turn, promote major comprehension of the role of cougars in the Colombian Cordilleras and lead actions for their conservation.
\end{abstract}

Key-Words. Biomass; Conflict; Conservation; Mammals; Prey.

\section{INTRODUCTION}

The cougar or mountain lion (Puma concolor) is a highly adaptable feline that has the most extensive range of all wild terrestrial mammals in America, since it is found from Canada through the United States, Central, and South America up to southern Chile (Nielsen et al., 2015). In Colombia, it has been registered in contrasting habitats, in an elevational range from sea level up to $4,100 \mathrm{~m}$, in the departments of Amazonas, Antioquia, Bolívar, Córdoba, Caldas, Cauca, Caquetá, Casanare, Chocó, Magdalena, Meta, Nariño, Norte de Santander, Putumayo, Risaralda, Sucre, Vaupés, and Vichada (Alberico et al., 2000; Jorgenson et al., 2006; Payan et al., 2007; Ramírez-
Chaves \& Noguera-Urbano, 2010; Payán Garrido \& Soto Vargas, 2012; Escobar-Lasso et al., 2014; Tinoco-Sotomayor et al., 2014; Racero-Casarrubia et al., 2015; Mosquera-Guerra et al., 2017; Pardo et al., 2017; Castaño et al., 2018; Jaimes et al., 2018).

The cougar is mainly nocturnal, although it can be active during daytime (Payán Garrido \& Soto Vargas, 2012). It has a generalist diet, so it can eat large preys, but it usually consumes small and medium-sized mammals (MacDonald et al., 2010). The cougar hunts alone, stalking and jumping on prey; the most frequent method is breaking the neck of its prey biting them in the throat (Crawshaw \& Quigley, 2002; Borrero et al., 2016). Most of known preys are mammals such as deer (Cervidae) and coatis (Procyonidae), followed by 
birds; even turning to carrion opportunistically (Bauer et al., 2005; Payán Garrido \& Soto Vargas, 2012). Studies of cougar diet in several places of the Americas (e.g., Chinchilla, 1997; Franklin et al., 1999) have found that its prey varies according to the place in which it is found. In temperate habitats, cougars consume a smaller variety of prey of larger size (one prey can represent $70 \%$ of the diet), whereas in tropical habitats it consumes a wider variety of prey of small size (one prey corresponds to only $28 \%$ of the diet; Iriarte et al., 1990). A prey of "medium" size in tropical habitats was four times larger than the average of countries with temperate habitats (61\% vs. $14 \%$; Iriarte et al., 1990).

Despite being a charismatic species, the information of $P$. concolor biology in Colombia is scarce (SuárezCastro \& Ramírez-Chaves, 2015; Jaimes et al., 2018). In addition, its diet has been poorly studied, with available information restricted to mentions of generalist diet, mainly mammals (Payán Garrido \& Soto Vargas, 2012; Jaimes et al., 2018). Particularly in Colombia only two studies have evaluated the cougar diet. The first was done in the high Andes and páramo ecosystems in the Central-Eastern Cordillera in the department of Cauca (Hernández-Guzmán et al., 2011), and the second in Andean, high Andean and páramo ecosystems of the northern part of the Eastern Cordillera, in the department of Norte de Santander (Jaimes et al., 2018). In the first study (Hernández-Guzmán et al., 2011) the cougar diet consisted mainly of five species, the little red brocket (Mazama rufina), northern pudu (Pudu mephistophiles; main prey), the western mountain coati (Nasuella olivacea), and the tawny-breasted tinamou (Nothocercus julius). In the second study (Jaimes et al., 2018) eight items, including the coati (Nasua nasua), deer (Mazama rufina) and mountain paca (Cuniculus taczanowskii) were the most abundant prey found. At national level cougars suffer from high hunting pressure due to retaliation, however, in none of the two available studies of cougar diet in Colombia, domestic species were reported. Nevertheless, the cougar eradication cases in Colombia are based on the premises that it frequently kill domestic animals (Jorgenson et al., 2006).

Apart of the retaliation hunting, cougar suffer extensively pressures by habitat deterioration, and it has been assessed in Colombia as Near Threatened (NT; Jorgenson et al., 2006). To mitigate these conflicts, all the ecological information on $P$. concolor diet from different localities in Colombia might be useful to seek alternatives to minimize the conflicts. Due to its generalist behavior, it is probable that its diet varies in different areas of Colombia, thus, to determine the diet of the cougar P. concolor in the Central Andes of the Coffee Region of Colombia we reviewed food items and biomass present in cougar scats.

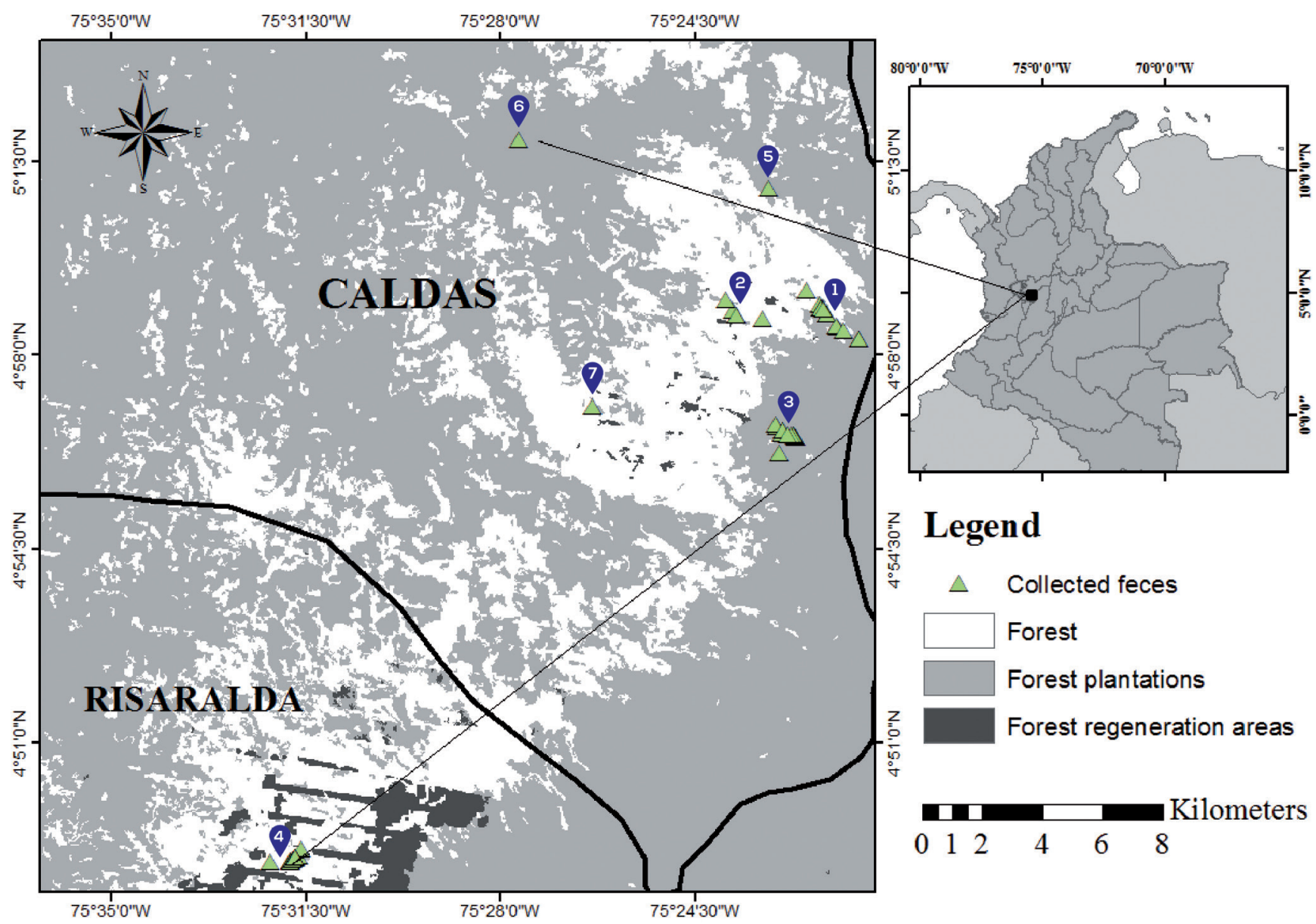

Figure 1. Places of collected puma scats within Central Andes of Colombia. The localities are: (1) Camino de La Fe, (2) El Topacio, (3) Romeral II, (4) Los Alpes, (5) Torre Cuatro, (6) La Enea, and (7) La María. 


\section{MATERIAL AND METHODS}

\section{Study area}

This study was carried out in two areas: (1) the Reserva Forestal Protectora Bosques CHEC $\left(04^{\circ} 52^{\prime} \mathrm{N}\right.$, $\left.75^{\circ} 24^{\prime} \mathrm{W}\right)$, located in the western slope of the Central Cordillera of Colombia. This area covers the department of Caldas and Risaralda, and it is located between the Western and Central Cordilleras of Colombia in the jurisdiction of the municipalities of Manizales and Villamaría, department of Caldas, Colombia (Roncancio \& Estévez, 2007). The protected area has an extension of approximately 3,893 ha and an elevational range between 2,400 and $4,000 \mathrm{~m}$. The reserve is connected in the upper part with National Natural Park (PNN) Los Nevados that protects high Andean forest and subpáramo ecosystems (Ramírez-Mejía \& Sánchez, 2015). (2) The conservation site of the "Central Hidroeléctrica de Caldas" (CHEC), Los Alpes, located on the western slope of the Central Cordillera of Colombia $\left(04^{\circ} 48^{\prime} \mathrm{N}, 75^{\circ} 31^{\prime} \mathrm{W}\right)$, in jurisdiction of the municipality of Santa Rosa de Cabal, department of Risaralda Colombia (Fig. 1) (CHEC, 2007). Los Alpes has 499.2 ha and an elevational range between 2,900 and $3,800 \mathrm{~m}$, and is connected in the upper part with the PNN Los Nevados and is immersed in the life zones called Andean forest, Andean high forest, subpáramo and páramo (CHEC, 2007).
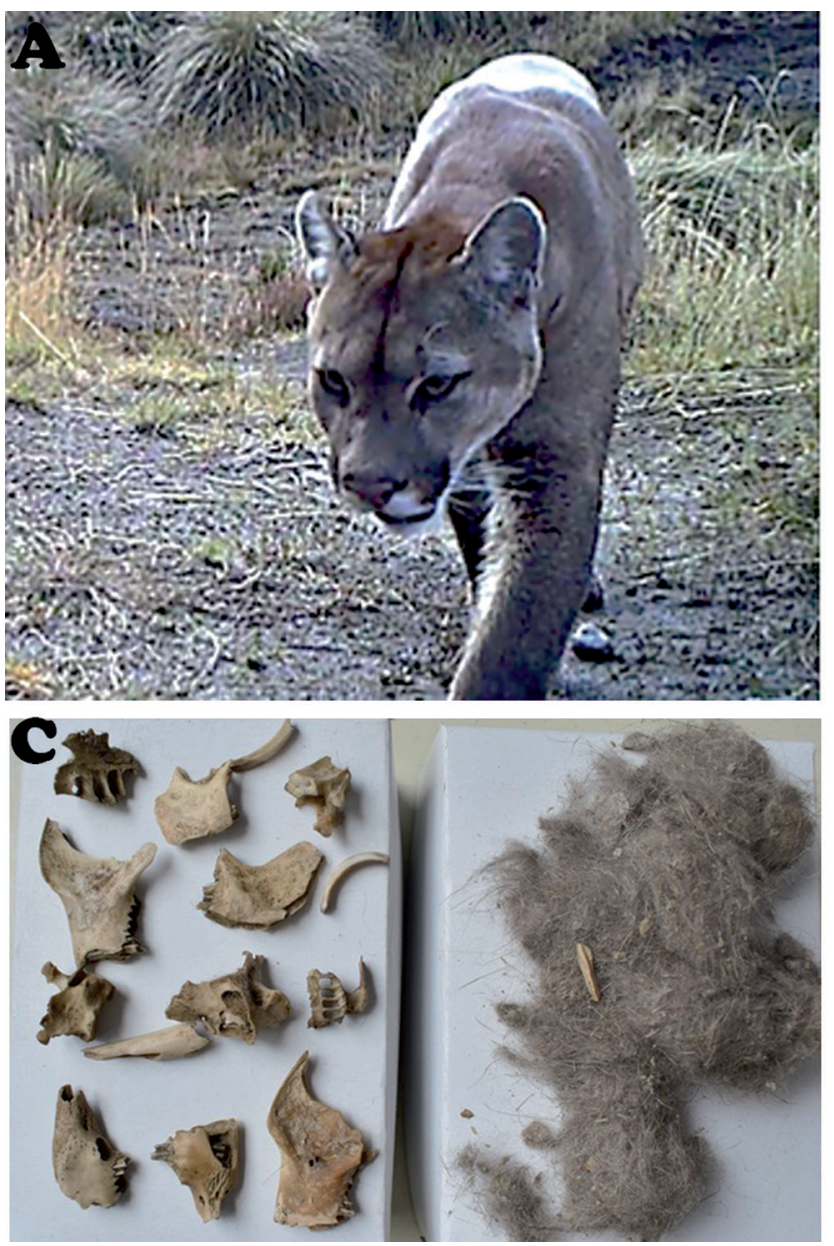

During 2015 and 2017, we collected opportunistically 53 cougar feces in repeated routes in places where the presence of Puma concolor was recorded using camera traps. The feces were found in the following locations (Fig. 1) at the Reserve: Camino de La Fé ( $n=18), E$ Topacio $(n=5)$, Romeral II $(n=13)$, Los Alpes $(n=14)$, Torre Cuatro $(n=1)$, La Enea $(n=1)$, and La Maria $(n=1)$. The identification of the feces was based on the size, the cylindrical shape, and the presence of bones and cougar hairs (Aranda Sánchez, 2012). Samples were stored in plastic bags, labeled and dried at room temperature in a ventilated place or in a furnace at the Museo de Historia Natural, Universidad de Caldas (MHN-UCa, catalogue numbers 3077-3078, 3117-3138, 3146-3157) where they were finally stored. Dry weight was recorded.

To identify the prey remains contained in the feces, the latter were first disintegrated in soapy water through a sieve and spread on a tray. Fragments of hair, skin, claws, bones, hooves, and other diagnostic standard elements were then separated, according to published methods (e.g., Hernández-Guzmán et al., 2011). Occasionally, the remains were separated directly from the dry sample and then washed with soap and water. We identified hairs found in the feces based on their general appearances such as color, length, width, thickness, and texture (Fig. 2). Mammal species were mostly identified at the species level. Identification of bone remains was carried out by direct comparison with reference specimens at the MHN-UCa.

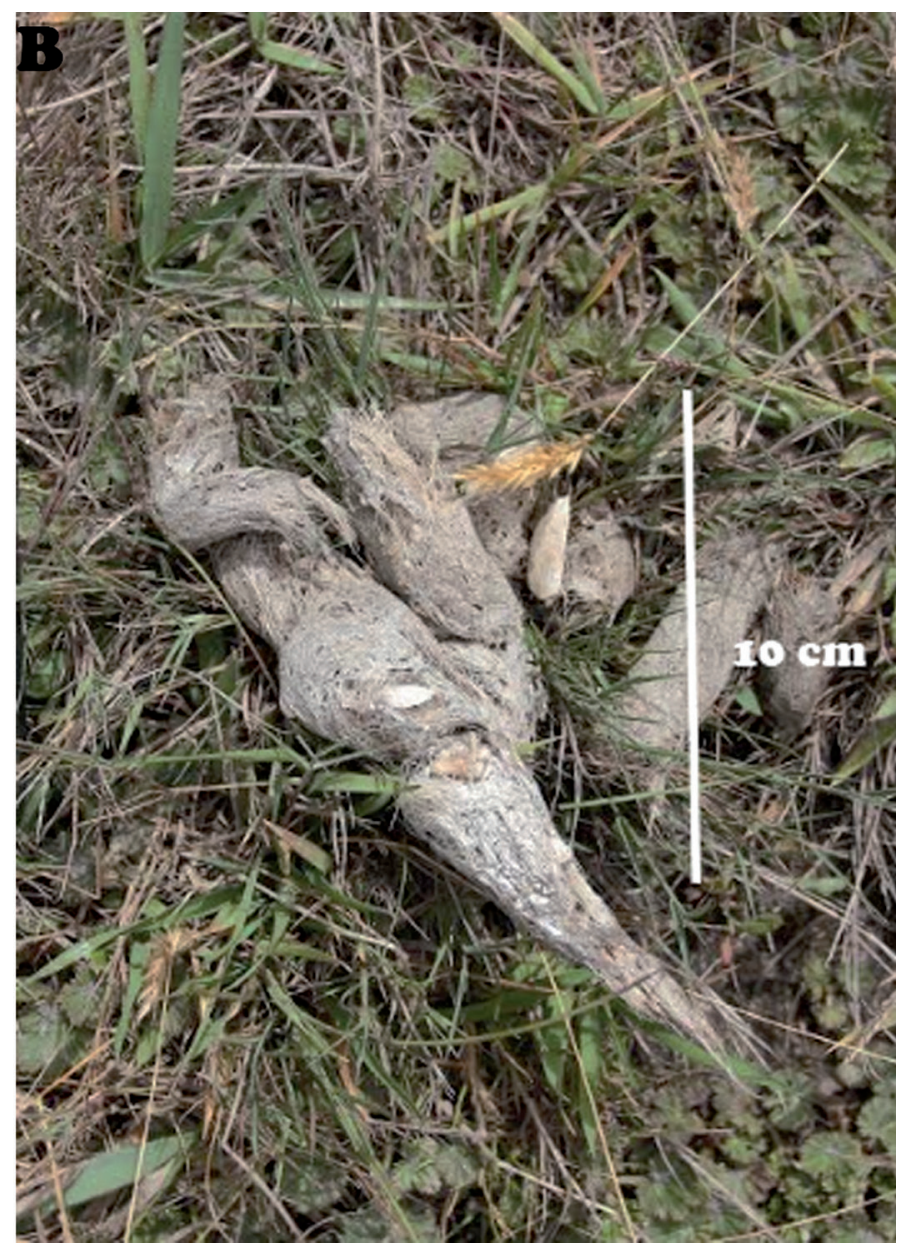

Figure 2. (A) Puma concolor photographed by camera trap in study area. (B) Feces sample. (C) Bones and hair separated from the sample. 
We considered faunal reports in the study area (CHEC, 2007) as a first approach to the cougar's food supply.

\section{Data analysis}

To estimate the minimum number of samples required to describe the cougar diet, we calculated a curve of accumulation of species using EstimateS version 9.10. We calculated the percentage of occurrence (\% PO) as the number of times a prey was found among all the prey. The percentage of frequency of occurrence (\% FO) was estimated as the number of feces in which a given prey was found (Maehr \& Brady, 1986; Johnson \& Franklin, 1991). The composition of the diet, taken as a percentage of occurrence, tends to overestimate the importance of large prey and underestimate the importance of small prey (Ackerman et al., 1984; Reynolds \& Aebischer, 1991), for this reason, we calculated the relative consumed biomass using a correction factor (Ackerman et al., 1984). The correction factor was not used on prey that weighs less than $2 \mathrm{~kg}$. The estimated mass of the prey was obtained from the literature (e.g., Eisenberg, 1989). To estimate the amplitude of the niche, we used the " $B$ " index of Levins (1968): $\mathrm{B}=1$ / $\Sigma \mathrm{Pi} 2$ where $\mathrm{Pi}$ is the percentage of individuals in category $\mathrm{i}$, and to standardize the niche measurement was made with the equation suggested by Hurlbert (1978): $B$ sta $=B-1 / n-1$, where $B$ is the index of Levins and $n$, number of possible resources (Krebs, 1999). The percentage of occurrence frequency of prey species was analyzed considering the dry and rainy seasons (Molano \& Batista, 1967). Finally, we performed a comparison of prey species of cougars with the items found in literature of its diet in the Andes (Pacheco et al., 2004, Hernández-Guzmán et al., 2011, Jaimes et al., 2018), and with the diet of the ocelot (Leopardus pardalis), from a closer locality to the Reserve (Sánchez et al., 2008).

\section{RESULTS}

We collected 53 cougar feces between March 2015 and February 2018. In addition, we detected three latrines frequently used by this species in the study area. We identified seven mammal species in the cougar diet of the orders Didelphimorphia, Pilosa, Artiodactyla, Rodentia and Lagomorpha. The highest biomass contribution (Fig. 3) was from Lagomorpha (49.94\%), followed by Rodentia (21.13\%), Didelphimorphia (10.45\%), Artiodactyla (9.76\%), and Pilosa (8.73\%). $11 \%$ of the skeletal remains in the feces could not be identified due to their fragmentary state.

The percentage of frequency of occurrence (Table 1) showed that the main type of prey was Sylvilagus sp. (58.49\%), followed by Coendou rufescens and Didelphis pernigra ( $11.32 \%$ respectively). In terms of consumed relative biomass, Sylvilagus sp. was the most important prey since it recorded the highest contribution of biomass (49.94\%), followed by D. pernigra (10.45\%), C. rufescens (10.20\%), and Mazama rufina (9.76\%) (Table 1). We found
Table 1. Species consumed by Puma concolor at the Central Andes of the Coffee region of Colombia. P0 \% = Percentage of Occurrence; F0 \% = Frequency of Occurrence; Weight $(\mathrm{kg})=$ Prey weight taken from Eisenberg (1989); Correction factor from Ackerman et al. (1984); B \% = Consumed relative biomass.

\begin{tabular}{|c|c|c|c|c|c|}
\hline Prey species & $\%$ PO & $\% \mathrm{FO}$ & Weight (kg) & Correction factor & $\% \mathrm{Bi}$. \\
\hline \multicolumn{6}{|l|}{ Didelphimorphia } \\
\hline Didelphis pernigra & 9.84 & 11,32 & 5,50 & 2,17 & 10,45 \\
\hline \multicolumn{6}{|l|}{ Pilosa } \\
\hline Choloepus hoffmanni & 8.20 & 9,43 & 5,70 & 2,18 & 8,73 \\
\hline \multicolumn{6}{|l|}{ Artiodactyla } \\
\hline Mazama rufina & 8.20 & 9,43 & 13,00 & 2,44 & 9,76 \\
\hline \multicolumn{6}{|l|}{ Rodentia } \\
\hline Cuniculus taczanowskii & 8.20 & 9,43 & 10,00 & 2,33 & 9,34 \\
\hline Coendou rufescens & 9.84 & 11,32 & 4,00 & 2,12 & 10,20 \\
\hline Unidentified small rodent & 0.04 & 1,89 & 0,04 & 1,98 & 1,59 \\
\hline \multicolumn{6}{|l|}{ Lagomorpha } \\
\hline Sylvilagus sp. & 54.10 & 58,49 & 0,85 & 2,01 & 49,94 \\
\hline
\end{tabular}

Table 2. Percentage of occurrence (P0) of species found in 53 Puma concolor feces between March 2015 and February 2018. Rain season covers March, April, May, June, September, October, November, and December. Dry season covers December, January, February, March, June, July, August, and September.

\begin{tabular}{|c|c|c|c|c|c|c|c|c|c|c|c|}
\hline \multirow[b]{2}{*}{ Prey species } & \multirow[b]{2}{*}{$\%$ PO } & \multicolumn{10}{|c|}{ Months of occurrence } \\
\hline & & ฐ్ & 인 & $\sum^{\frac{\pi}{\pi}}$ & 趸 $\frac{\bar{a}}{\Sigma}$ & 三 & $\Xi$ & 운 ฝำ & 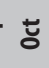 & 훌 & ธั้ \\
\hline Didelphis pernigra & 9,84 & & & $x$ & & $x$ & & $x$ & & $x$ & \\
\hline Choloepus hoffmanni & 8,20 & & $x$ & $x$ & & $x$ & $x$ & & $x$ & & \\
\hline Mazama rufina & 8,20 & & $x$ & $x$ & $x$ & & & & & & \\
\hline Cuniculus taczanowskii & 8,20 & & & & & $x$ & & $x$ & & $x$ & \\
\hline Coendou rufescens & 9,84 & & $x$ & $x$ & & & & $x$ & & & \\
\hline Unidentified small rodent & 0,04 & & & & & & & $\mathrm{x}$ & & & \\
\hline Sylvilagus sp. & 54,10 & & $x$ & $x$ & $x$ & $x$ & & $x$ & $x$ & & $\mathrm{x}$ \\
\hline
\end{tabular}

no domestic species in the samples. The calculated Puma concolor trophic niche amplitude was estimated at 0.33 (Bsta), which indicates that the species is a predator with a specialized tendency in the study area (values closer to 0 are assigned to a specialized diet, whereas values closer to 1 indicate a generalist diet). Almost all registered prey were consumed by the cougar during both seasons (dry and rainy), except for $C$. rufescens and the unidentified rodent that was found only in the dry season (Table 2).

When cougar prey items in the study area were compared with the information available for Colombia (Hernández-Guzmán et al., 2011; Jaimes et al., 2018), we found several shared mammal species such as Didelphis pernigra, Choloepus hoffmanni, Nasuella olivacea, Mazama rufina, Cuniculus taczanowskii, and Sylvilagus sp. When the cougar diet in Colombia was compared with information from Bolivia (Pacheco et al., 2004), we found no common preys. Comparing the diet of the cougar with the diet of the ocelot in an area near to the Reserve (Sánchez et al., 2008), showed some common prey items such as Nasuella olivacea, Coendou rufescens, and Sylvilagus sp. However, the ocelot consumed other rodents such as Neomicroxus cf. bogotensis, Chilomys instans, Dinomys branickii, Microryzomys minutus, and Thomasomys gr. aureus. 


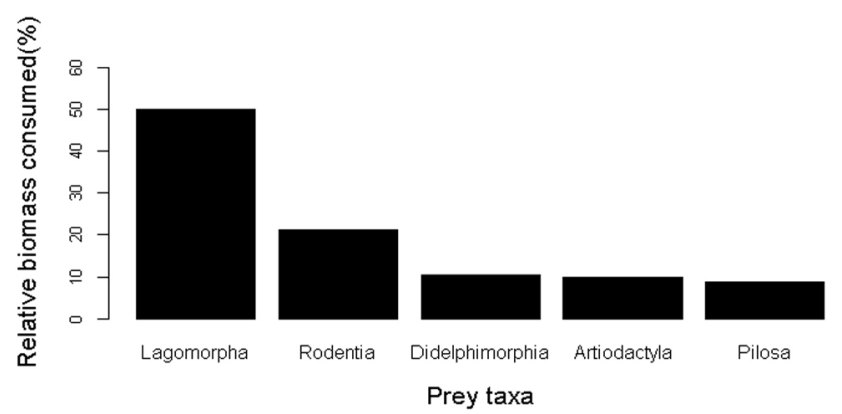

Figure 3. Relative biomass of prey orders found in Puma concolor feces at the Central Andes of Colombia.

\section{DISCUSSION}

The present study adds important observations about the cougar diet in the Central Andes of Colombia, where this species had not been studied. In general, studies on the cougar diet in Colombia, and in the Andean part of South America are scarce so, this information is crucial to understand the diet of this carnivore in the country. As found in other studies (Hernández-Guzmán et al., 2011; Jaimes et al., 2018), the tendency was to observe high frequency of small and medium-size mammals in the cougar diet. When the prey consumed by the cougar in Colombia and Bolivia were compared (Pacheco et al., 2004; Hernández-Guzmán et al., 2011; Jaimes et al., 2018), no prey was found that was present in all the studies, however, Nasuella olivacea, Didelphis sp., Mazama ru-

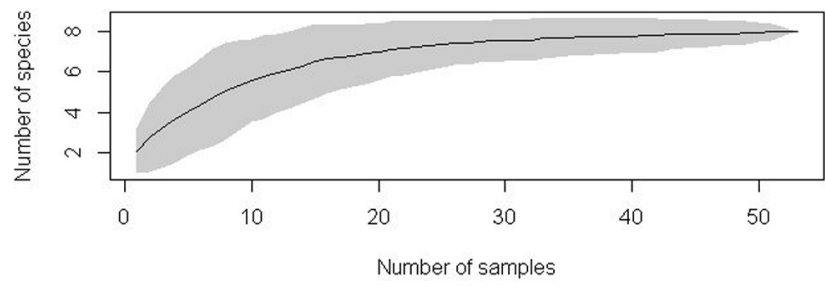

Figure 4. Species accumulation curve for species richness and a non-parametric estimator of species richness Chao 2 at several sectors of the Central Andes of the Coffee Region in Colombia. The species accumulation curve indicates that the sampling shows $100 \%$ of the species consumed by the cougar in this area.

fina, and Silvylagus sp. are common prey items (Table 3). In particular, Coendou rufescens constitutes a new record for the diet of this feline in the country. It has been also shown that small-sized mammals have the larger biomass contributes to the cougar diet. For example, the Northern Pudu (Pudu mephistophiles) had the higher biomass contribution (59.7\%) at the National Natural Park (PNN) Puracé (Hernández-Guzmán et al., 2011). At the PNN Tamá (Jaimes et al., 2018), the cougar consumed mainly the South American coati (Nasua nasua) and the little red brocket (Mazama rufina), which are small and medium-sized prey, while in the Sajama National Park, Bolivia, medium and small rodents were present in $45 \%$ of the samples, contributing $38.7 \%$ in biomass (Pacheco et al., 2004). The accumulation curve approached the asymptote with approximately 53 scat samples (Fig. 4).

Table 3. Prey species comparison of studies of the diet of Puma concolor in the Colombian Cordilleras (Col) and the Bolivian Andes (Bol).

\begin{tabular}{|c|c|c|c|c|}
\hline \multirow{2}{*}{ Prey Species } & \multicolumn{4}{|c|}{ Studies in the Andes of Bolivia and Colombia } \\
\hline & Pacheco et al. (2004): Bol. & Hernández-Guzmán et al. (2011): Col. & Jaimes et al. (2018): Col. & This Work (Col). \\
\hline \multicolumn{5}{|l|}{ MAMMALIA } \\
\hline \multicolumn{5}{|l|}{ Didelphimorphia } \\
\hline Didelphis pernigra & & & & $x$ \\
\hline \multicolumn{5}{|l|}{ Cingulata } \\
\hline Dasypus novemcinctus & & & $x$ & \\
\hline \multicolumn{5}{|l|}{ Pilosa } \\
\hline Choloepus hoffmanni & & & $x$ & $x$ \\
\hline \multicolumn{5}{|l|}{ Carnivora } \\
\hline Nasua nasua & & & $x$ & \\
\hline Nasuella olivacea & & $x$ & $x$ & \\
\hline Conepatus chinga & $x$ & & & \\
\hline Lycalopex culpaeus & $x$ & & & \\
\hline \multicolumn{5}{|l|}{ Artiodactyla } \\
\hline Pudu mephistophiles & & $x$ & & \\
\hline Mazama rufina & & $x$ & $x$ & $x$ \\
\hline Lama glama/pacos & $\mathrm{x}$ & & & \\
\hline Vicugna vicugna & $x$ & & & \\
\hline \multicolumn{5}{|l|}{ Rodentia } \\
\hline Coendou rufescens & & & & $x$ \\
\hline Cuniculus taczanowskii & & & $x$ & $x$ \\
\hline Dasyprocta punctata & & & $x$ & \\
\hline \multicolumn{5}{|l|}{ Lagomorpha } \\
\hline Sylvilagus brasiliensis & & $X$ & & \\
\hline Sylvilagus sp. & & & & $x$ \\
\hline \multicolumn{5}{|l|}{ AVES } \\
\hline \multicolumn{5}{|l|}{ Tinamiforme } \\
\hline Nothocercus julius & & $x$ & & \\
\hline
\end{tabular}


The calculation of the amplitude trophic niche (Bsta $=0.33$ ) indicated that the cougar is a specialist carnivore. However, similar findings for this species in the Puracé National Natural Park (Hernández-Guzmán et al., 2011), indicate that this value is not showing, precisely, a specialized diet in the cougar. The review of the cougar's food items in South America (Table 3) supports the idea that cougar's eating habits are generalist. It seems that, in the study area, this result is biased by the abundance of Silvylagus sp. which represented $50 \%$ in frequency of occurrence. The high presence of cottontail rabbits in the diet of the cougar might be explained by the fact that small mammals are a relatively abundant resource for the predator and its consumption is advantageous in terms of the amount of energy ingested compared to search effort and handling risk (Bisceglia et al., 2008).

The marked differences observed between the cougar diet and other smaller cats such as the ocelot (Leopardus pardalis) might be explained by the lack of capacity of the ocelot to capture prey of the same size as other larger cats such as cougars or jaguars (Emmons, 1987) since small carnivores obtain up to $70 \%$ of their daily metabolic energy from rodents (Mukherjee et al., 2004). In the Central Andes of Colombia small mammals weighing less than $400 \mathrm{~g}$ represent $51.72 \%$ of the prey in their diet (Sánchez et al., 2008). In places where the cougar shares habitat with other big cats such as the jaguar, diet of these two species can be very similar (Taber et al., 1997).

The absence of domestic species in the diet of the cougar in the study area can indicate a positive factor in areas where there may be conflicts with humans due to opportunistic depredation of domestic fauna. It is possible that the cougar has no need to approach human settlements because it had enough food supply in the area since large cats are more likely to kill cattle, sheep, and goats when the biomass of wild prey decreases. The probability of cattle slaughter by big cats increases significantly when the biomass of the prey reaches some minimum thresholds (Khorozyan et al., 2015).

Finally, to have a better knowledge of the cougar diet in Colombia and contribute to its conservation, we recommend making samplings in both dry and rainy seasons of along the year so that a tentative relationship in the prey preference of the cougar can be evaluated. It is also necessary to make a larger sampling effort in this area to have more complete information about the prey species present in the diet of this feline.

\section{ACKNOWLEDGMENTS}

We thank the Centro de Museos, Museo de Historia Natural, Universidad de Caldas for allowing us access to the Mammals and trichology collection and laboratory. The Fundación Ecológica Cafetera and the Central Hidroeléctrica de Caldas (CHEC) allowed access to the properties and provided us with the necessary information for this study. Thanks to the Sociedad Colombiana de Etnobiología; and the Zoologische Gesellschaft für Arten un Populatiosschutz (ZGAP) for support. HER-C thanks Rufford Small Grants (Grant 29491-2) project "The Status of Some Highly Hunted Endemic Rodents and Deer of Colombia". Viviana Gonzalez-Astudillo and Catalina Cárdenas provided useful comments that improved early versions of the manuscript.

\section{REFERENCES}

Ackerman, B.B.; Lindzey, F.G. \& Hemker, T.P. 1984. Cougar food habits in southern Utah. The Journal of Wildlife Management, 48(1): 147-155.

Alberico, M.; Cadena, A.; Hernández Camacho, J. \& Muñoz Saba, Y. 2000. Mamíferos (Synapsida:Theria) de Colombia. Biota colombiana, 1(1):43-75.

Aranda Sánchez, J.M. 2012. Manual para el rastreo de mamifferos silvestres de México. Cueranavaca, Méx., Comisión Nacional para el conocimiento y uso de la Biodiversidad (Conabio).

Bauer, J.W.; Logan, K.A.; Sweanor, L.L. \& Boyce, W.M. 2005. Scavenging Behavior in Puma. Southwest Naturalist, 50(4): 466-471.

Bisceglia, S.B.; Pereira, J.A.; Teta, P. \& Quintana, R.D. 2008. Food habits of Geoffroy's cat (Leopardus geoffroyi) in the central Monte desert of Argentina. Journal of Arid Environments, 72(6): 1120-1126.

Borrero, L.A.; Martin, F.M. \& Prevosti, F.J. 2016. Taphonomy and the role of pumas (Puma concolor) in the formation of the archaeological record. Quaternary International, 466(part B): 157-164.

Castaño, J.H.; Torres, D.A.; Rojas-Díaz, V.; Saavedra-Rodríguez, C.A. \& PérezTorres, J. 2018. Mamíferos del Departamento de Risaralda, Colombia. Biota Colombiana, 18(2): 239-254.

Central Hidroeléctrica de Caldas (CHEC). 2007. Plan de manejo y conservación de flora y fauna y aprovechamiento ecoturistico de la Reserva Forestal de la CHEC S.A. E.S.P. Manizales, Central Hidroeléctrica de Caldas. 212p.

Chinchilla, F.A. 1997. La dieta del jaguar (Panthera onca), el puma (Felis concolor) y el manigordo (Felis pardalis) (Carnivora; Felidae) en el Parque Nacional Corcovado, Costa Rica. Revista de Biología Tropical, 45(3): 1223-1230.

Crawshaw Jr., P.G. \& Quigley, H.B. 2002. Hábitos alimentarios del jaguar y el puma en el Pantanal, Brasil, con implicaciones para su manejo y conservación. In: Medellín, R.A.; Equihua, C.; Chetkiewicz, C.L.B.; Crawshaw Jr., P.G.; Rabinowitz, A.; Redford, K.H.; Robinson, J.G.; Sanderson, E.W. \& Taber, A.B. (Eds.). El jaguar en el nuevo milenio. México, Fondo de Cultura Económica, UNAM, WCS. p. 223-235.

Eisenberg, J.F. 1989. Mammals of the Neotropics Vol. 1. The Northern Neotropics: Panama, Colombia, Venezuela, Guyana, Suriname, French Guiana. Chicago,University of Chicago Press. 449p.

Emmons, L.H. 1987. Comparative feeding ecology of felids in a neotropical rainforest. Behavioral Ecology and Sociobiology, 20(4): 271-283.

Escobar-Lasso, S.; Cerón-Cardona, J.; Castaño-Salazar, J.H.; Mendieta-Giraldo, L. \& Ospina-Herrera, 0. 2014. Los felinos silvestres del departamento de Caldas, en la región andina de Colombia: composición, distribución y conservación. Therya, 5(2): 575-588.

Franklin, W.L.; Johnson, W.E.; Sarno, R.J. \& Iriarte, J.A. 1999. Ecology of the Patagonia puma Felis concolor patagonica in southern Chile. Biological Conservation, 90(1): 33-40.

Hernández-Guzmán, A.; Payán, E. \& Monroy-Vilchis, 0. 2011. Hábitos alimentarios del Puma concolor (Carnivora: Felidae) en el Parque Nacional Natural Puracé, Colombia. Revista de Biología Tropical, 59(3): 1285-1294.

Hurlbert, S.H. 1978. The measurement of niche overlap and some relatives. Ecology, 59(1): 67-77.

Iriarte, J.A.; Franklin, W.L.; Johnson, W.E. \& Redford, K.H. 1990. Biogeographic variation of food habits and body size of the America puma. Oecologia, 85(2): 185-190. 
Jaimes, R.P.; Cáceres-Martínez, C.H.; Acevedo, A.A.; Arias-Alzate, A. \& González-Maya, J.F. 2018. Food habits of puma (Puma concolor) in the Andean areas and the buffer zone of the Tamá National Natural Park, Colombia. Therya, 9(3): 201.

Johnson, W.E. \& Franklin, W.L. 1991. Feeding and spatial ecology of Felis geoffroyi in southern Patagonia. Journal of Mammalogy, 72(4): 815-820.

Jorgenson, J.P.; Rodríguez-Mahecha, J.V. \& Durán-Ramírez, C. 2006. Puma. Puma concolor. In: Rodríguez, M.J.V.; Alberico, F.T. \& Jorgenson, J.P. (Eds.). Libro Rojo de los Mamíferos de Colombia. Serie Libros Rojos de Especies Amenazadas de Colombia. Bogotá, Colombia, Ministerio del Medio Ambiente, Vivienda y Desarrollo Territorial. p. 349-355.

Khorozyan, I.; Ghoddousi, A.; Soofi, M. \& Waltert, M. 2015. Big cats kill more livestock when wild prey reaches a minimum threshold. Biological Conservation, 192: 268-275.

Krebs, C.J. 1999. Ecological methodology. 2.ed. Menlo Park, Addison Wesley Longman. 620p.

Levins, R. 1968. Evolution in changing environments: one theoretical explorations. Princeton, N.J., Princeton University Press. 120p.

MacDonald, D.W.; Loveridge, A.J. \& Nowell, K. 2010. Dramatis personae: An introduction to the wild felids. In: MacDonald, D.W. \& Loveridge, A.J. (Eds.). Biology and conservation of wild Felids. Oxford, England, Oxford University. p. 3-58.

Maehr, D.S. \& Brady, J.R. 1986. Food habits of bobcats in Florida. Journal of Mammalogy, 67(1): 133-138.

Molano, C.J. \& Batista, J.M. 1967. Calendario climatológico aeronáutico colombiano. Boletín de la Sociedad Geográfica de Colombia, 25: 95-6.

Mosquera-Guerra, F.; Trujillo, F.; Mantilla-Meluk, H. \& Díaz-Pulido, A. 2017. Caracterización biológica de la cuenca del río Bita (Vichada, Colombia). In: Trujillo, F. \& Lasso, C.A. (Eds.). Biodiversidad del Rio Bita Vichadal Colombia. Bogotá, Instituto de Investigación de Recursos Biológicos Alexander von Humboldt. p. 297-333. (Serie editorial Recursos hidrobiológicos y pesqueros continentales de Colombia)

Mukherjee, S.; Goyal, S.P.; Johnsingh, A.J.T. \& Pitman, M.L. 2004. The importance of rodents in the diet of jungle cat (Felis chaus), caracal (Caracal caracal) and golden jackal (Canis aureus) in Sariska Tiger Reserve, Rajasthan, India. Journal of Zoology, 262(4): 405-411.

Nielsen, C.;Thompson, D.; Kelly, M.\& Lopez-Gonzalez,CA. 2015. Puma concolor. Available at: https://www.iucnredlist.org/species/18868/97216466. Access in: 04/10/2018.

Pacheco, L.F.; Lucero, A. \& Villca, M. 2004. Dieta del puma (Puma concolor) en el Parque Nacional Sajama, Bolivia y su conflicto con la ganadería. Ecología en Bolivia, 39(1): 75-83.
Pardo, L.E.; Clements, G.R.; Edwards, W.; Rojas-Rojas, A.V. \& Laurance, W.F. 2017. Registros de puma (Puma concolor Linnaeus, 1771) en zona rural de San Carlos de Guaroa, Meta, Colombia. Revista Biodiversidad Neotropical, 7(2): 104-109.

Payán Garrido, E. \& Soto Vargas, C. 2012. Los Felinos de Colombia. Bogotá, Ministerio de Ambiente y Desarrollo Sostenible, Instituto de Investigaciones de Recursos Biológicos Alexander von Humboldt y Panthera.

Payan, E.; Quiceno, M.P. \& Franco, A.M. 2007. Los felinos como especies focales y de alto valor cultural. Bogotá, Instituto de Investigación de Recursos Biológicos Alexander von Humboldt. (Serie especies colombianas, 7)

Racero-Casarrubia, J.; Ballesteros-Correa, J. \& Pérez-Torres, J. 2015. Mamíferos del departamento de Córdoba-Colombia: historia y estado de conservación. Biota Colombiana, 16(2): 128-148.

Ramírez-Chaves, H.E. \& Noguera-Urbano, E.A. 2010. Lista preliminar de los mamíferos (Mammalia: Theria) del departamento de Nariño, Colombia. Biota Colombiana, 11 (1 y 2): 115-138.

Ramírez-Mejía, A.F. \& Sánchez, F. 2015. Non-volant mammals in a protected area on the Central Andes of Colombia: new records for the Caldas department and the Chinchiná River basin. Check list, 11(2): 1582.

Reynolds, J.C. \& Aebischer, N.J. 1991. Comparison and quantification of carnivore diet by faecal analysis: a critique, with recommendations, based on a study of the fox Vulpes vulpes. Mammal Review, 21(3): 97-122.

Roncancio, N. \& Estévez, J. 2007. Evaluación del ensamblaje de murciélagos en áreas sometidas a regeneración natural y a restauración ecológica por medio de plantaciones de aliso. Boletín Científico, Museo de Historia Natural Universidad de Caldas, 11(1): 131-143.

Sánchez, F.; Valencia, B.G.; Álvarez, S. \& Laverde, M.G. 2008. Primeros datos sobre los hábitos alimentarios del tigrillo, Leopardus pardalis, en un bosque andino de Colombia. Revista UDCA Actualidad y Divulgación Científica, Colombia, 11(2): 101-107.

Suárez-Castro, A.F. \& Ramírez-Chaves H.E. (Eds.). 2015. Los carnívoros terrestres y semiacuáticos continentales de Colombia. Guía de Campo. Bogotá, Universidad Nacional de Colombia. 113p.

Taber, A.B.; Novaro, A.J.; Neris, N. \& Colman, F.H. 1997. The food habits of sympatric jaguar and puma in the Paraguayan Chaco. Biotropica, 29(2): 204-213.

Tinoco-Sotomayor, A.N.; Ramos-Guerra, H.D. \& González-Maya, J.F. 2014. Registros recientes de cacería de felinos silvestres y confirmación de la presencia de puma (Puma concolor) en la zona de amortiguamiento del Santuario de Fauna y Flora El Corchal "El Mono Hernández", Colombia. Mammalogy Notes, 1(2): 11-12. 